\title{
СПЕЦИФІКА ГЕНОТИПОВОЇ СТРУКТУРИ РІЗНИХ ПОРІД СВІЙСЬКИХ СОБАК ЗА МІКРОСАТЕЛІТАМИ ДНК
}

\author{
Шельов Андрій Володимирович \\ кандидат сільськогосподарських наук, ст. науковий співробітник \\ Інститут розведення і генетики тварин ім. М.В. Зубця, НАAН \\ ORCID: 0000-0003-1496-9667 \\ E-mail: shelyov@gmail.com
}

Копилов Кирило В'ячеславович доктор сільськогосподарських наук, професор Інститут розведення і генетики тварин ім. М.В. Зубця, НААН ORCID: 0000-0001-5243-3447

E-mail: kopylkir@ukr.net

Крамаренко Сергій Сергійович доктор біологічних наук, професор Миколаївський національний аграрний університет ORCID: 0000-0001-5658-1244

E-mail: Kssnail0108@gmail.com

Крамаренко Олександр Сергійович кандидат сільськогосподарських наук, доцент Миколаївський національний аграрний університет ORCID: 0000-0002-2635-526X E-mail: kssnail1990@gmail.com

Хмельничий Леонтій Михайлович доктор сільськогосподарських наук, профессор Сумський національний аграрний університет ORCID: 0000-0001-5175-1291

E-mail: khmelnychy@ukr.net

В результаті аналізу генотипового поліморфізму свійських собак (Сanis саnis) Встановлено, що найбільшим рівнем поліморфізму за показниками генотипової мінливості ( $\left.\mathrm{Ng}=18,4 ; \mathrm{Ng}_{1}=8,6 ; \mathrm{Ng}_{2}=4,8 \mathrm{ma} \mathrm{Ng}_{\text {unic }}=5,8\right)$ характеризуються тварини породи німещька вічарка, середнім рівнем генотпової мінливості характеризувались російські тойтер'єри $\left(\mathrm{Ng}=10,8 ; \mathrm{Ng}_{1}=5,8 ; \mathrm{Ng}_{2}=3,2\right.$ ma $\left.\mathrm{Ng} g_{\text {unic }}=1,4\right)$, а найбільш консолідованою на генотиповому рівні виявилась порода німецький дог ( $\mathrm{Ng}=10,4 ; \mathrm{Ng}_{1}=5 ; \mathrm{Ng}_{2}=3$ ma $\left.\mathrm{Ng}_{\text {unic }}=0\right)$. За 2 з 5 досліджених мікросателітних локусів (FHC2010 та FHC2054) сnектри генотипового поліморфізму в усіх досліджених порід були однаковими за своїм розмахом (Lim $\mathrm{Ng})$, за рештою локусів найменшим розмахом характеризуються німецькі доги, а найбільшим - вівчарки. Російські той-тер'єри характеризуються максимальним розмахом спектрів генотипового поліморфізму, за локусами PEZ01 та FHC2010, i середнім розмахом за локусом PEZ06 (174-202 п.н.). Найчастіше, для 4-х мікросателітних локусів з 5 досліджених (крім PEZ06) найбільшою кількістю генотипових варіантів ( $\mathrm{Ng}=18,4)$ характеризуються вівчарки. За локусом PEZO6 найбільшу кількість генотипових варіантив ( $\mathrm{Ng}=14)$ виявлено у той тер'єрів. За рештою локусів кількість виявлених генотипів між догами та той тер'єрами відрізнялась несуттєво (1-4 генотипи). Слід відмітити, що відмінності між дослідженими породами за кількістю виявлених генотипових варіантів була достовірною лише для локусів PEZO6 (p<0,001) та FHC2054 (p<0,05). Bci досліджені мікросателітні локуси характеризувались середньою кількістю $(15,5)$ різних генотипових варіантів. Загальна їх кількість у особин даного виду коливалась від 15 (за локусом FHC2010) до 27 (за локусом FHC2054). При цьому, найвищий рівень генотипового поліморфізму було зафіксовано за локусом PEZO8 у німецьких вівчарок ( $\mathrm{Ng}=24)$. Найменш поліморфним виявився локус FHC2010 у тварин породи російський той тер'єр (Ng=7). В усіх досліджених породах, за всіма локусами зафріксовано певну консолідованість за окремими генотипами. За 3 з 5 локусів (PEZ01, PEZ08 та FHC2010) у представників порід німецька вівчарка та німецький дог ці генотипи були однаковими, за цими ж локусами було виявлено однакові найпоширеніші генотипи і в вівчарок та той тер'єрів, а в догів і тойтер'єрів однакові найпоширеніші генотипи було виявлено за локусами PEZO6 та FHC2054. Причому, генотunu PEZ06 182/206, PEZ06 166/174, FHC2054168/172, FHC2054140/160 ma FHC2054156/160 є породоспецифрічними для вівчарок.

Ключові слова: собаки, мікросателіти, поліморфізм, ДНК, породоспецифічні генотипи.

DOI: https://doi.org/10.32845/bsnau.Ivst.2020.4.19

Особливий інтерес до вивчення генетичної структури порід собак, який спостерігається протягом останніх десятирічь [1], зумовлений не лише тим, що це один з найраніше доместикованих видів тварин, що за деякими даними відбулось більше 10000 років тому, а й тим, що вони

зазнали мабуть найбільшого впливу з боку людини [2] Роботи з вивчення структури геному представників даного виду за мікросателітними локусами ДНК тривають з кінця минулого тисячоліття і $€$ актуальними досі [3]. Так, геном свійського собаки було розшифровано ще у 2004 році, 
одним з перших [4]. За даними, отриманими в вересні 2011 г. (CanFam 3.1), геном C. familiaris содержит 2,392 х $10^{9}$ п.н., 19856 кодуючих генів та 11898 некодуючих генів [5].

Для селекціонерів та генетиків дослідження генетичної структури даного виду за високо поліморфними генетичними системами становить великий інтерес ще й тому, що він залишається одним з небагатьох де дуже часто в селекційній роботі використовується тісний інбридинг, що дає велику кількість матеріалу для дослідження його наслідків [6].

Крім досліджень історії доместикації, популяційної структури окремих порід, відмінностей між ними, експертизи достовірності походження особин в останні роки з'являються роботи присвячені діагностиці раку та інших спадково обумовлених захворювань у собак. Велика кількість досліджень мікросателітів у пов'язано з криміналістикою [7].

Тому, з метою, оцінки генотипового різноманіття, в рамках проведення молекулярно-генетичного моніторингу, нами було проведено роботу з дослідження особливостей генетичної структури свійських собак трьох порід, а саме: службової породи - німецька вівчарка, однієї з найстаріших - німецький дог та декоративної - російський той-тер'єр.

Матеріали та методи досліджень. Молекулярногенетичний аналіз було проведено на зразках біоматеріалу відібраного від 79 голів собак, порід німецька вівчарка (39 голів), німецький дог (20 голів) та російський той-тер'єр (20 голів). Всі тварини належали приватним власникам, які $€$ членами Федерації службово-спортивного собаківництва України.

Для відбору зразків букального епітелію, робили мазок зі слизової оболонки щік. Для цього використовували ватні палички, які потім висушували на повітрі [8]. Виділення ДНК зі зразків крові здійснювали з використанням набору «ДНК-сорб-В» (Амплісенс, Росія), згідно рекомендацій виробника. Дослідження генетичної структури проводили на наступному обладнанні: ПЛР проводили на ампліфікаторі AB 2720 Thermal Cycler (Applied Biosystems, США). Реакційну суміш для ПЛР готували згідно протоколу рекомендованого виробником тест-системи (Stock Marcs, 2010) [9]. Ампліфіковану ДНК розділяли методом капілярного гельелектрофорезу на генетичному аналізаторі ABI Prism 3130 Genetic Analyzer (Applied Biosystems, США). Документування отриманих графічних результатів здійснювалось за допомо- гою програм «Run 3130 Data Collection v.3.0» (Applied Biosystems, США) та «GeneMapper 3.7» (Applied Biosystems, США). Мікросателітний аналіз проводили за п'ятьма мікросателітними локусами (PEZ01, PEZ06, PEZ08, FHC2010 та FHC2054) що входять до переліку рекомендованих Міжнародним товариством з генетики тварин (ISAG) та Американським клубом собаківництва (АКС) [10-12].

Для оцінки алельного різноманіття було використано: кількість виявлених алелів (Na) розраховану за допомогою програми GenAlEx v. 6.5 [13]. Крім того, за використання програми HP-rare v.1.0 [14] було одержано оцінки алельного різноманіття $\left(\mathrm{AR}_{40}\right)$ й кількості породоспецифічних алелів (PAR 40 ) для 40 випадковим чином відібраних з кожної вибірки особин, що дозволило провести коректне порівняння алельного різноманіття, не залежно від об'єму вибірки. Для порівняння порід в цілому відносно показників алельного різноманіття було використано непараметричний дисперсійний аналіз Фрідмана. Всі розрахунки було проведено за використання програми PAST [15].

Результати досліджень. По виду загалом за 5 мікросателітними локусами було виявлено 112 різних генотипових варіантів (табл. 1).

За локусом PEZO1 було виявлено 22 генотипових варіанти. Генотип PEZ0196/108 відмічено у 10 особин. Цей самий генотип найчастіше зустрічався у собак породи німецька вівчарка та російський той-тер'єр (відмічений у 5 особин). У тварин породи німецький дог найпоширенішими були генотипи PEZ01116/132 та PEZ01 124/132, що відмічені у 4 особин.

Локус PEZO8 було представлено 26 різними генотипами. Найбільш поширенішим був генотип PEZ08218/218 (відмічено у 8 особин). Він же був наймасовішим у вівчарки та той-тер'єру (у 4 особин). У дога найчастіше зустрічався генотип PEZO8222/246.

15 різних генотипових варіантів було виявлено за локусом HFC2010, що склало 18,99\% від загальної кількості виявлених генотипів. Найпоширенішим по виду був генотип HFC2010244/244 (відмічений у 13 особин). Цей самий генотип був найпоширенішим у німецькій вівчарки та дога (відмічено у 7 особин в кожній), а у той-тер'єру - генотип HFC2010228/236.

За локусом PEZO6 було виявлено 22 різних генотипових варіантів. Найпоширенішими були генотипи PEZ06 170/202 та PEZ06182/206 (відмічені у 9 особин, кожен).

Таблиця 1

Кількість виявлених генотипів ( $\mathrm{Ng})$ у різних породах собак

\begin{tabular}{|c|c|c|c|c|c|}
\hline \multirow{2}{*}{ Локус } & \multicolumn{3}{|c|}{ По породі } & \multirow{2}{*}{ По виду, загалом } & По виду, в середньому \\
\cline { 2 - 4 } & HВ & НД & РТ & 22 & 15,75 \\
\hline PEZ01 & 22 & 10 & 9 & 26 & 18,5 \\
\hline PEZ08 & 24 & 13 & 11 & 15 & 12 \\
\hline FHC2010 & 15 & 11 & 7 & 22 & 13,75 \\
\hline PEZ06 & 11 & 8 & 14 & 27 & 17,5 \\
\hline FHC2054 & 20 & 10 & 13 & 22,4 & 15,5 \\
\hline середнє & 18,4 & 10,4 & 10,8 & \\
\hline
\end{tabular}

У вівчарки найпоширенішим був генотип PEZ06186/202 (відмічений у 9 особин), у дога - PEZ06 166/178 та PEZ06170/202 (відмічені у 5 особин, кожен), останній генотип був найрозповсюдженішим і у той-тер'єра (відмічений у 4 особин).

За локусом FHC2054 виявлено 27 різних генотипових варіантів. Найбільше розповсюдження по виду загалом були генотипи FHC2054140/168 та FHC2054144/156 (відмічені у 7 особин, кожен). У німецькій вівчарки найпоширенішим (відміче- ний у 5 особин) був генотип $\mathrm{FHC2054}{ }^{168 / 172}$, а у дога FHC2054144/156 (відмічений у 4 особин), а у той-тер'єра генотипи FHC2054140/172 та FHC2054144/156 (відмічені у 3 особин).

В усіх породах, за всіма дослідженими локусами зафіксовано певну консолідованість за окремими генотипами. За 3 з 5 мікросателітних локусів (PEZ01, PEZ08 та FHC2010) у німецькій вівчарки та дога ці генотипи були однаковими, за цими ж локусами було виявлено однакові найпоширеніші 
алелі у німецькій вівчарки та той-тер'єрі, а в той-тер'єрі та дога однакові найпоширеніші генотипи було виявлено за локусами PEZ06 та FHC2054. Причому, генотипи PEZ06182/206, PEZ06166/174, FHC2054168/172, FHC2054140/160 та FHC2054156/160 є породоспецифічними для вівчарки.

За чотирма локусами з п'яти у вівчарки встановлений вищий рівень поліморфрізму ніж у представників решти досліджених порід. А за локусом PEZO6 найполіморфнішими були російський той-тер'єр. Крім того в усіх породах виявлено рідкісні генотипові варіанти, тобто генотипи, що зустрічаються в популяціях лише по одному (табл. 2) та по два (табл. 3) рази.

Таким чином, за 2 з 5 досліджених мікросателітних локусів (FHC2010 та FHC2054) спектри генотипового полі- морфізму в усіх досліджених порід були однаковими за своїм розмахом $\left(\operatorname{Lim}_{N g}\right)$, за рештою мікросателітів найменшим розмахом характеризується німецький дог, а найбільшим - німецька вівчарка. Представники породи російський той-тер'єр характеризуються максимальним розмахом спектрів генотипового поліморфізму, за локусами PEZ01 та FHC2010, і середнім розмахом за локусом PEZ06 (166-206 п.н.). Найчастіше, для 4-х мікросателітних локусів з 5 досліджених (крім PEZO6) найбільшою кількістю генотипових варіантів $(\mathrm{Ng}=18,4)$ характеризуються особини, що належать до породи німецька вівчарка. За локусом PEZO6 найбільшу кількість генотипових варіантів $(\mathrm{Ng}=14)$ виявлено у російського той-тер'єру.

Таблиця 2

\section{Кількість виявлених генотипів $\left(\mathrm{Ng}_{1}\right)$ у різних порід собак}

\begin{tabular}{|c|c|c|c|c|c|}
\hline \multirow{2}{*}{ Локус } & \multicolumn{3}{|c|}{ По породі } & \multirow{2}{*}{ По виду, загалом } & По виду, в середньому \\
\cline { 2 - 4 } & HB & НД & PT & 5 & 6,25 \\
\hline PEZ01 & 12 & 5 & 3 & 6 & 7,75 \\
\hline PEZ08 & 13 & 7 & 5 & 0 & 3,66 \\
\hline FHC2010 & 4 & 5 & 2 & 7 & 5,33 \\
\hline PEZ06 & 3 & 3 & 10 & 10 & 8,5 \\
\hline FHC2054 & 11 & 5 & 8 & 5,4 & 6,467 \\
\hline середнє & 8,6 & 5 & 5,8 & & \\
\hline
\end{tabular}

За рештою локусів кількість виявлених генотипів між догами та той тер'єрами відрізнялась несуттєво (1-4 генотипи). Слід відмітити, що відмінності між дослідженими породами за кількістю виявлених генотипових варіантів була достовірною лише для мікросателітних локусів PEZO6 ( $p$ < $0,001)$ та FHC2054 ( $<<0,05)$.

Всі досліджені мікросателітні локуси характеризува- лись середньою кількістю $(15,5)$ різних генотипових варіантів. Загальна їх кількість у особин даного виду коливалась від 15 (за локусом FHC2010) до 27 (за локусом FHC2054). При цьому, найвищий рівень генотипового поліморфізму було зафіксовано за локусом PEZO8 у особин, що належать до породи німецька вівчарка $(\mathrm{Ng}=24)$. Найменш поліморфним виявився локус FHC2010 у той-тер'єрів $(\mathrm{Ng}=7)$.

Таблиця 3

Кількість виявлених генотипів $\left(\mathrm{Ng}_{2}\right)$ у різних порід собак

\begin{tabular}{|c|c|c|c|c|c|}
\hline \multirow{2}{*}{ Локус } & \multicolumn{3}{|c|}{ По породі } & \multirow{2}{*}{ По виду, загалом } & По виду, в середньому \\
\cline { 2 - 4 } & $\mathrm{HB}$ & НД & РТ & 6 & 4,5 \\
\hline PEZ01 & 6 & 2 & 3 & 7 & 6,25 \\
\hline PEZ08 & 8 & 5 & 4 & 2 & 3,5 \\
\hline FHC2010 & 6 & 5 & 3 & 4 & 2,5 \\
\hline PEZ06 & 1 & 2 & 3 & 2 & 2,25 \\
\hline FHC2054 & 3 & 1 & 3 & 4,2 & 3,667 \\
\hline середнє & 4,8 & 3 & 3,2 & \\
\hline
\end{tabular}

Породоспецифічні генотипи (табл.4) у німецького догу були відсутні. У німецької вівчарки було виявлено 29 таких генотипів, а саме: PEZ01104/112; PEZ01108/128. PEZ01112/116; PEZ01116/116; PEZ01124/124; PEZO8218/250; PEZ08222/254, PEZ08242/250; PEZ06166/166; PEZ06 166/174; PEZ06 174/174; PEZO6 174/190; PEZ06 182/182; PEZO6 182/190; PEZO6182/182; PEZO6206/206 'HFC2054140/148;' HFC2054140/156.
HFC2054140/160; HFC2054140/164; HFC2054148/148; HFC2054148/160; HFC2054156/160; HFC2054156/172; HFC2054160/160; HFC2054 160/164; HFC2054160/168; HFC2054160/172; HFC2054164/168 та HFC2054168/172. А у російського той-тер'єру - 7, а саме: PEZO8214/250, PEZ08254/254; PEZ06178/187 PEZ06190/194; PEZ06 198/206; PEZO6202/202 та HFC2054 156/168.

Таблиця 4

Кількість виявлених генотипів ( $\left.\mathrm{Ng}_{\text {unik }}\right)$ у різних порід собак

\begin{tabular}{|c|c|c|c|c|c|}
\hline \multirow{2}{*}{ Локус } & \multicolumn{3}{|c|}{ По породі } & По виду, загалом & По виду, в середньому \\
\cline { 2 - 4 } & HВ & НД & РТ & 5 & 1,67 \\
\hline PEZ01 & 5 & 0 & 0 & 5 & 1,67 \\
\hline PEZ08 & 3 & 0 & 2 & 0 & 0 \\
\hline FHC2010 & 0 & 0 & 0 & 11 & 3,67 \\
\hline PEZ06 & 8 & 0 & 4 & 15 & 5 \\
\hline FHC2054 & 14 & 0 & 1 & 7,2 & 2,4 \\
\hline
\end{tabular}

Локуси PEZ01 ( $\left.X^{2}=44.01 ; d f=42 ; p_{м c}=0,395\right)$, PEZ08 $\left(X^{2}=45,017 ; d f=50 ; p_{м c}=0,769\right)$ та HFC2010 $\left(X^{2}=33,707 ; d f=\right.$ 28; $\left.p_{\text {мс }}=0,205\right)$ не мали вірогідні відмінності між частотами за окремими генотипами (табл.5). А за локусами
PEZO6 ( $\left.X^{2}=82,838 ; d f=42 ; p_{M c}=0,0002\right)$ та FHC2054 $\left(X^{2}=\right.$ 65,413; $\left.d f=52 ; p_{м с}=0,0489\right)$ відмінності, що спостерігалися між частотами окремих генотипових варіантів серед собак різних порід, є вірогідними. 
Ступінь генетичної диференціації між породами собак за розподілом частот генотипів мікросателітних локусів ДНК

\begin{tabular}{|c|c|c|c|}
\hline Локус & $d f$ & $x^{2}$ & $p$ \\
\hline PEZ01 & 14 & 53,12 & 0,0001 \\
\hline PEZ08 & 32 & 75,76 & 0,0001 \\
\hline FHC2010 & 24 & 80,88 & 0,0001 \\
\hline PEZ06 & 16 & 44,51 & 0,0001 \\
\hline FHC2054 & 20 & 50,44 & 0,0002 \\
\hline
\end{tabular}

За непараметричним методом А. Чао, використання якого дозволяє більш коректно здійснити порівняння популяцій різного розміру, в цілому, відмічається різний характер розподілу кількості генотипів, але в цілому, розрахунки одержані за допомогою даного методу, зберігають відповідність попередньо одержаним результатам безпосереднього аналізу.

Висновки. В результаті аналізу генотипового поліморфізму свійських собак (Canis familiaris L.) встановлено, що найбільшим рівнем поліморфізму за показниками генотипової мінливості ( $\mathrm{Ng}=18,4 ; \mathrm{Ng}_{1}=8,6, \mathrm{Ng}_{2}=4,8$ та $\left.\mathrm{Ng}_{\text {unic }}=5,8\right)$ характеризуються тварини породи німецька вівчарка, сере- днім рівнем генотипової мінливості характеризувались російський той-тер'єр $(10,8 ; 5,8 ; 3,2$ та 1,4), а найбільш консолідованою на генотиповому рівні виявилась порода німецький дог (10,4; 5; 3 та 0). Що відповідає історії розведення та специфіці селекційної роботи з дослідженими породами.

Водночас встановлено суттєвий ступень подібності між дослідженими породами, за розмахом спектрів генотипового поліморфізму та його відмінність за характером розподілу виявлених генотипів, кількістю виявлених $(\mathrm{Ng})$, рідкісних $\left(\mathrm{Ng}_{1}, \mathrm{Ng}_{2}\right)$ та унікальних генотипів ( $\left.\mathrm{Ng}_{\text {unic }}\right)$.

\section{Список використаної літератури:}

1. Тарасенкова Н. А. Коптев В. В. Значение ДНК маркеров для развития современного собаководства. Вестник АПК Верхневолжья. 2015.1 (29). С. 44-52.

2. Yilmaz, O. Controversies of Origin of Domestic Dog-III-References of Modern Dogs until 2006. Sch J Agric Vet Sci. 2017. 4(11). P. 484-490.

3. Ostrander E. A., Dreger D. L., Evans J. M. Canine Cancer Genomics: Lessons for Canine and Human Health. Annu Rev Anim Biosci. 2019. 15 (7). P. 449-472. doi: 10.1146/annurev-animal-030117-014523.

4. Lindblad-Toh K. Wade C. M., Mikkelsen T. S., Karlsson E. K., Jaffe D. B., [et al.]. Genome sequence, comparative analysis and haplotype structure of the domestic dog. Nature. 2005. 438. P. 803-819.

5. Dog assembly and gene annotation [Electronic resource] / Ed. P. Flicek. - The European Bioinformatics Institute, Sanger Institute, 2000. - Mode of access : http://www.ensembl.org/Canis_familiaris/lnfo/Annotation. - Date of access : 12.09.2016.

6. Altet L., Francino O., Sanchez A. Microsatellite Polymorphism in Closely Related Dogs. Journal of Heredity. 2001. 92(3). P.276-279. doi: $10.1093 /$ ihered/92.3.276

7. Graham, E. A., Nonhuman DNA. Forensic science, medicine, and pathology. 2005. 1(2), 159-161.

8. Дзіцюк В. В., Ященко В. М., Круглик С. Г., Мельник О. В., Шельов А. В., Спиридонов В. Г., Мельничук С. Д. Генетична ідентифікація собак. Київ.: Видавничий центр НУБіП України. 2012. 33 с.

9.https://www.thermofisher.com/order/catalog/product/4349041\#/4349041

10. Hellmann A. P., Rohleder U., Eichmann C., Pfeiffer I., Parson W., Schleenbecker U. A proposal for standardization in forensic canine DNA typing: allele nomenclature of six canine-specific STR loci. J Forensic Sci. 2006. 51(2). P. 274-81. doi: 10.1111/j.1556-4029.2006.00049.x.

11. Kanthaswamy S., Tom B. K., Mattila A. M., Johnston E., Dayton M., Kinaga J., Erickson B. J., Halverson J., Fantin D., De Nise S., Kou A., Malladi V., Satkoski J., Budowle B., Smith D. G., Koskinen M. T. Canine population data generated from a multiplex STR kit for use in forensic casework. J Forensic Sci. 2009. 54(4). P. 29-40. doi: 10.1111/j.1556-4029.2009.01080.x.

12. Tom B. K., Koskinen M. T., Dayton M., Mattila A. M., Johnston E., Fantin D., Denise S., Spear T., Smith D.G., Satkoski J., Budowle B., Kanthaswamy S. Development of a nomenclature system for a canine STR multiplex reagent kit. J Forensic Sci. 2010. 55(3). P. 597-604. doi: 10.1111/j.1556-4029.2010.01361.x.

13. Peakall R., Smouse P. E. GenAIEx 6.5: genetic analysis in Excel. Population genetic software for teaching and research - an update. Bioinformatics. 2012. 28. P. 2537-2539.

14. Kalinowski S. T. HP-Rare: a computer program for performing rarefaction on measures of allelic diversity. Molecular Ecology Notes. 2005. 5. P. 187-189.

15. Hammer O., Harper D. A. T., Ryan P. D. PAST: Paleontological statistics software package for education and data analysis. Palaeontologia Electronica. 2001. 4. P. 1-9.

\section{References:}

1. Tarasenkova, N.A. Koptev, V.V., 2015. Znacheniye DNK markerov dlya razvitiya sovremennogo sobakovodstva [The value of DNA markers for the development of modern dog breeding]. Agroindustrial Complex of Upper Volga Region Herald, no. 1 (29), pp. 44-52.

2. Yilmaz, O., 2017. Controversies of Origin of Domestic Dog-III-References of Modern Dogs until 2006. Sch J Agric Vet Sci, no. 4 (11), pp. 484-490.

3. Ostrander, E.A., Dreger, D.L., Evans, J.M., 2019. Canine Cancer Genomics: Lessons for Canine and Human Health. Annu Rev Anim Biosci, no. 15 (7), pp. 449-472. doi: 10.1146/annurev-animal-030117-014523. 
4. Lindblad-Toh, K., Wade, C.M., Mikkelsen, T.S., Karlsson, E.K., Jaffe, D.B., [et al.], 2005. Genome sequence, comparative analysis and haplotype structure of the domestic dog. Nature, no. 438 (7069) pp. 803-19. doi: 10.1038/nature04338.

5. Flicek. Ed.P., 2000. Dog assembly and gene annotation. The European Bioinformatics Institute, Sanger Institute, Available at: <http://www.ensembl.org/Canis_familiaris/Info/Annotation> [Accessed : 12.09.2016].

6. Altet, L., Francino, O., Sanchez, A., 2001. Microsatellite Polymorphism in Closely Related Dogs. Journal of Heredity, no. 92 (3), pp.276-279. doi: $10.1093 /$ hered/92.3.276

7. Graham, E.A., 2005. Nonhuman DNA. Forensic science, medicine, and pathology, no. 1 (2), pp. 159-161.

8. Dzitsyuk, V.V., Yashchenko, V.M., Kruhlyk, S.H., Mel'nyk, O.V., Shelyov, A.V., Spyrydonov, V.H. and Mel'nychuk, S.D., 2012. Henetychna identyfikatsiya sobak [Genetic identification of dogs]. Kyiv: Publishing Center of NUBiP, Ukraine.

9. StockMarks ${ }^{\mathrm{TM}}$ for Dogs Genotyping Kit, canine, with protocol. Available at: <https://www.thermofisher.com/order/catalog/product/4349041\#/4349041>

10. Hellmann, A.P., Rohleder, U., Eichmann, C., Pfeiffer, I., Parson, W., Schleenbecker, U., 2006. A proposal for standardization in forensic canine DNA typing: allele nomenclature of six canine-specific STR loci. J Forensic Sci, no. 51 (2), pp. 274-81. doi: 10.1111/j.1556-4029.2006.00049.x.

11. Kanthaswamy, S., Tom, B.K., Mattila, A.M., Johnston, E., Dayton, M., Kinaga, J., Erickson, B.J., Halverson, J., Fantin, D., De Nise, S., Kou, A., Malladi, V., Satkoski, J., Budowle B., Smith, D.G., Koskinen, M.T., 2009. Canine population data generated from a multiplex STR kit for use in forensic casework. J Forensic Sci, no. 54 (4), pp. 29-40. doi: 10.1111/j.1556-4029.2009.01080.x.

12. Tom, B.K., Koskinen, M.T., Dayton, M., Mattila, A.M., Johnston, E., Fantin, D., Denise, S., Spear, T., Smith, D.G., Satkoski, J., Budowle, B., Kanthaswamy, S., 2010. Development of a nomenclature system for a canine STR multiplex reagent kit. J Forensic Sci, no. 55 (3), pp. 597-604. doi: 10.1111/j.1556-4029.2010.01361.x.

13. Peakall, R., Smouse, P.E. 2012. GenAlEx 6.5: genetic analysis in Excel. Population genetic software for teaching and research - an update. Bioinformatics, no. 28, pp. 2537-2539.

14. Kalinowski, S.T., 2005. HP-Rare: a computer program for performing rarefaction on measures of allelic diversity. Molecular Ecology Notes, no. 5, pp. 187-189.

15. Hammer, O., Harper, D.A.T., Ryan, P.D., 2001. PAST: Paleontological statistics software package for education and data analysis. Palaeontologia Electronica, no. 4, pp. 1-9.

Shelov Andrii Volodymyrovych, Candidate of Agricultural Sciences, Art. Researcher

Kopilov Kyrylo Viacheslavovych, Doctor of Agricultural Sciences, Professor

Institute of Animal Breeding and Genetics nd. a. M.V.Zubets of NAAS (Chubynske, Ukraine)

Kramarenko Serhii Serhiiovych, doctor of biological sciences professor

Kramarenko Oleksandr Serhiiovych, candidate of agricultural sciences, docent

Nikolaev National Agrarian University (Nikolaev, Ukraine)

Khmelnychyi Leontii Mykhailovych, Doctor of Agricultural Sciences, Professor

Sumy National Agrarian University (Sumy, Ukraine)

Specificity of genotypic structure of different breeds of domestic dogs by microscatelites of DNA

As a result of the analysis of genotypic polymorphism of domestic dogs (Canis canis) it is established that the highest level of polymorphism in terms of genotypic variability $\left(\mathrm{Ng}=18.4 ;\left(\mathrm{Ng}=18,4 ; \mathrm{Ng}_{1}=8,6 ; \mathrm{Ng}_{2}=4,8\right.\right.$ and $\left.\mathrm{Ng}_{\text {unic }}=5,8\right)$ 5.8) is characterized by animals of the German Shepherd breed, the average level of genotypic variability was characterized by Russian Toy Terriers (Ng=10,8; $N g_{1}=5,8 ; \mathrm{Ng}_{2}=3$,2and $\left.\mathrm{Ng}_{\text {unic }}=1.4\right)$, and the most consolidated at the genotypic level was the Great Dane breed $(\mathrm{Ng}=10,4 ; \mathrm{Ng}=5$; $\mathrm{Ng}_{2}=3$ and $\mathrm{Ng}_{\text {unic }}=0$ ). For 2 of the 5 studied microsatellite loci (FHC2010 and FHC2054) the spectra of genotypic polymorphism in all studied rocks were the same in their scope $\left(\operatorname{Lim}_{\mathrm{Ng}}\right)$, for the rest of the loci the smallest scale is characterized by Great Danes, and the largest - puppies. Russian toy terriers are characterized by the maximum range of genotype polymorphism spectra, at the PEZ01 and FHC2010 loci, and the average range at the PEZ06 locus (174-202 bp). Most often, for 4 microsatellite loci out of 5 studied (except PEZ06), shepherds are characterized by the largest number of genotype variants $(\mathrm{Ng}=18.4)$. At the PEZO6 locus, the largest number of genotype variants $(\mathrm{Ng}=14)$ was found in those terriers. At the other loci, the number of detected genotypes differed insignificantly between Great Danes and Terriers (1-4 genotypes). It should be noted that the differences between the studied breeds in the number of detected genotype variants was significant only for loci PEZ06 ( $p<0.001)$ and FHC2054 ( $p<0.05)$. All studied microsatellite loci were characterized by an average number (15.5) of different genotypic variants. Their total number in individuals of this species ranged from 15 (at the locus FHC2010) to 27 (at the locus FHC2054). At the same time, the highest level of genotypic polymorphism was recorded at the locus PEZ08 in German shepherds ( $\mathrm{Ng}=24)$. The least polymorphic was the locus FHC2010 in animals of the Russian Toy Terrier breed ( $\mathrm{Ng}=7$ ). In all studied breeds, at all loci, a certain consolidation by individual genotypes was recorded. For 3 out of 5 loci (PEZ01, PEZ08 and FHC2010) in the German Shepherd and Great Dane breeds, these genotypes were the same, for the same loci the same most common genotypes were found in sheep and terriers, and in mastiffs and toy terriers. the same most common genotypes were detected at loci PEZ06 and FHC2054. Moreover, genotypes PEZ06 182/206, PEZ06 166/174, FHC2054168/172, FHC2054140/160 and FHC2054156/160 are breed-specific for shepherds.

Key words: dogs, microsatellites, polymorphism, DNA, breed-specific genotypes.

Дата надходження до редакції: 23.11.2020 р. 